Issued by Sandia National Laboratories, operated for the United States Department of Energy by Sandia Corporation.

NOTICE: This report was prepared as an account of work sponsored by an agency of the United States Government. Neither the United States Government, nor any agency thereof, nor any of their employees, nor any of their contractors, subcontractors, or their employees, make any warranty, express or implied, or assume any legal liability or responsibility for the accuracy, completeness, or usefulness of any information, apparatus, product, or process disclosed, or represent that its use would not infringe privately owned rights. Reference herein to any specific commercial product, process, or service by trade name, trademark, manufacturer, or otherwise, does not necessarily constitute or imply its endorsement, recommendation, or favoring by the United States Government, any agency thereof, or any of their contractors or subcontractors. The views and opinions expressed herein do not necessarily state or reflect those of the United States Government, any agency thereof, or any of their contractors.

Printed in the United States of America. This report has been reproduced directly from the best available copy.

Available to DOE and DOE contractors from

Office of Scientific and Technical Information

P.O. Box 62

Oak Ridge, TN 37831

Prices available from (703) 605-6000

Web site: http://www.ntis.gov/ordering.htm

Available to the public from

National Technical Information Service

U.S. Department of Commerce

5285 Port Royal Rd

Springfield, VA 22161

NTIS price codes

Printed copy: A02

Microfiche copy: A01

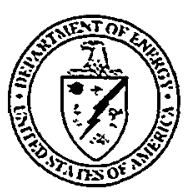




\section{DISCLAIMER}

Portions of this document may be illegible in electronic image products. Images are produced from the best available original document. 
SAND 99-2849

Unlimited Release

Printed November 1999

\title{
System of Labs Direct Fabrication Technology
}

M. E. Schlienger, M. Oliver and D. Dimos

Direct Fabrication Department

Sandia National Laboratories/New Mexico

P. O. Box 5800

Albuquerque, NM 87185-1411

\begin{abstract}
The System of Labs Direct Fabrication Technology program was intended to foster cooperation and development in a cooperative effort between Sandia National Labs, Idaho National Energy \& Environment Lab and Oak Ridge National Lab. The goal of this program was to bring together LENS (Laser Engineered Net Shaping) from Sandia, INEEL's spray forming process and the alloy development expertise of ORNL. This program investigated the feasibility of combining the LENS and spray forming processes to exploit the best features of both approaches. Further, since both processes were thought to result in a rapidly solidified structure, the alloy design expertise of ORNL offered the opportunity for alloy design or processing options which could more fully utilize the unique capabilities of the processes.
\end{abstract}




\section{System of Labs Direct Fabrication Technology}

\section{Introduction}

The System of Labs Direct Fabrication Technology program was intended to foster cooperation and development in a collaborative effort between Sandia National Labs, Idaho National Energy \& Environment Lab and Oak Ridge National Lab. The goal of this program was to bring together LENS (Laser Engineered Net Shaping) from Sandia, INEEL's spray forming process and the alloy development expertise of ORNL.

LENS is a laser based direct manufacturing process that starts with a CAD solid model. The model is decomposed into a series of layers of constant thickness. Each layer is then broken up into a series of raster lines of a specified thickness. A 3-axis system is then used to raster a laser beam along the resultant lines. The laser, a Nd-YAG device operated at about 300 watts, is focused on a substrate to form a molten pool. Powder is then injected into this molten pool thereby forming a bead. An X-Y table moves the substrate under the LENS head and the bead is pulled across the evolving part, resulting in the controlled deposition of metal. As the part builds up and a layer is completed, the LENS head is raised one layer height. This process is illustrated schematically in Fig. 1. The molten pool and powder stream can be clearly seen in Fig. 2, which is a photograph during processing.

One drawback of the LENS process is its speed. Present deposition rates are below $.25 \mathrm{cc} / \mathrm{min}$ and although experiments have shown scale up to be very feasible, there are techniques capable of producing near net shape metal components at much greater rates. The INEEL spray forming process is one such technique.

In the INEEL process, an RTV negative is made from a master part. This mold is then used to cast a ceramic form. The ceramic is cured and placed into the spray-forming device. Once the ceramic is in position, metal is inductively melted and delivered to the spray nozzle. The form is manipulated within the metal spray and a deposition builds up on the ceramic, as shown in Fig. 3. Once the spray process is completed, the ceramic is removed and the excess sprayed material is cut off. Although this process is fast, on the order of $50 \mathrm{cc} / \mathrm{min}$, "shadowing" of the metal spray makes the process unsuitable for high aspect ratio features.

The intent of this program was to investigate the feasibility of using combining these two processes such that the positive features of both might be exploited. Further, since both processes were thought to result in a rapidly solidified structure, the alloy design expertise of ORNL was seen as offering the opportunity for alloy design or processing options which could more fully utilize the unique capabilities of the processes.

\section{PROGRAM DEFINITION}

Initial planning meetings resulted a decision to build an injection-molding tool using an optimized alloy. The bulk portions of the tool were to be produced by INEEL using their spray forming process. High aspect ratio features were to be added with the LENS process. The first year tasks included tool design, evaluation of solidification conditions for the two processes, and evaluation of the interface between the two types of deposit. Second year goals were to design an 
that alloy's performance to several commercial tool steels. Finally the mold was to be produced and actually used to form plastic parts.

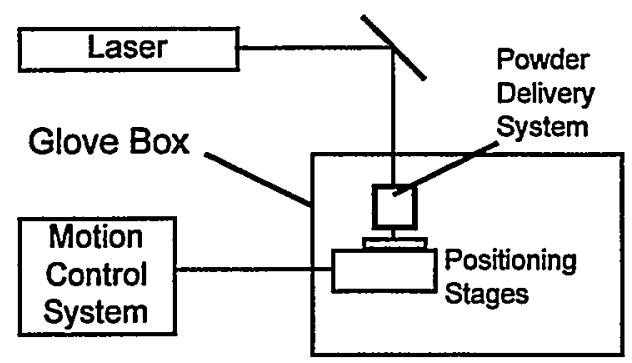

Figure 1. Schematic representation of the basic approach to laser depositing metallic materials.

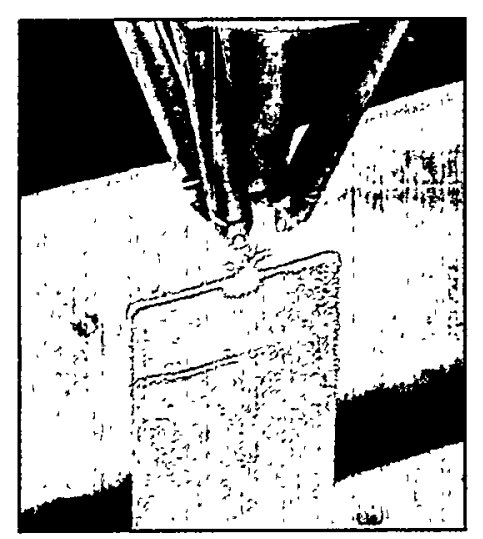

Figure 2. The LENS process is used to directly deposit metal into precise patterns.

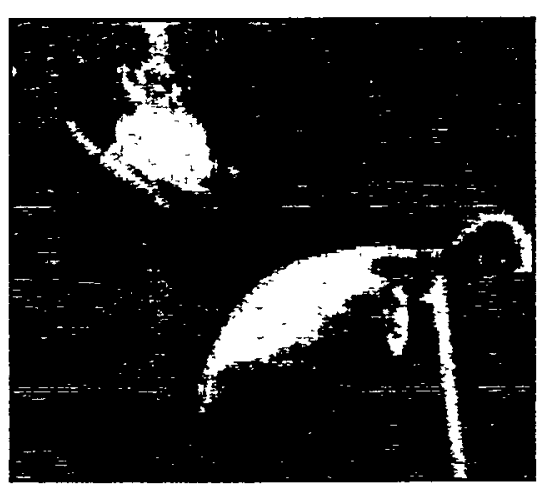

Figure 3. The INEEL spray forming process deposits metal at high deposition rates.

\section{RESULTS}

Sample parts of $\mathrm{H} 13$ tool steel were produced via the spray-form process. Subsequently, the LENS process was used successfully to add high-aspect ration features, as shown in Fig. 4.

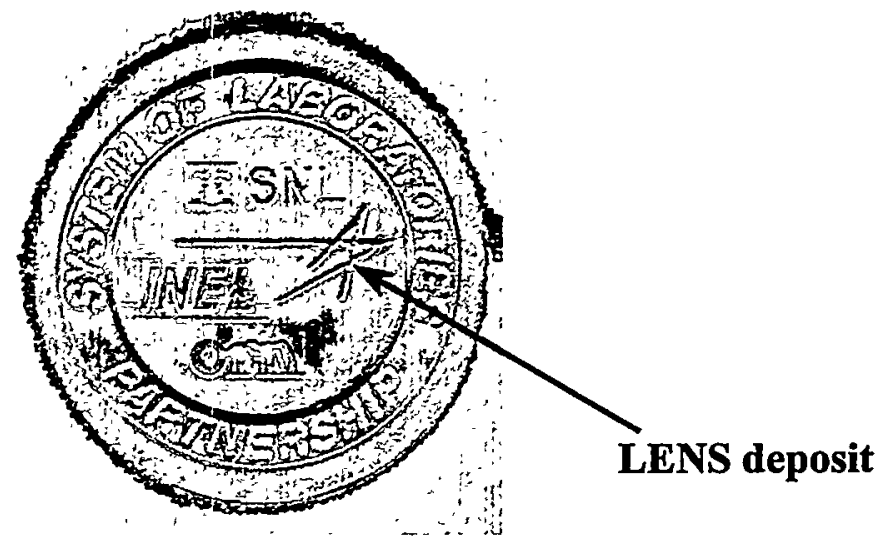

Figure 4. Tool steel (H13) die made by combining thermal spray and LENS processing.

Characterization of a composite part (Fig. 5) at INEEL, ORNL, and SNL has shown that materials fabricated through the combined processing approach exhibit a clear change in the microstructural evolution. Most important was the fact that the parts from the two processes are very different with regards to their thermal histories and solidification structure. While LENS exhibits a fully dense, 
rapidly solidified structure, the Spray-formed parts had a coarser, more porous structure. These structures are consistent with process observations which reveal that the entire spray-formed part glows quite hot for an extended period of time, on the order of a minute or more, while the LENS produced material is only glowing hot for a fraction of a second. These empirical observations clearly indicate a very different cooling rate, which is born out by the microstructure. In addition, the spray-formed material exhibits droplet boundaries and porosity, where the LENS material is fully dense, with no prior powder boundaries. However in LENS, the path of the molten pool during the deposition process is indicated by a variation in grain morphology that occurs along the prior molten pool boundaries.

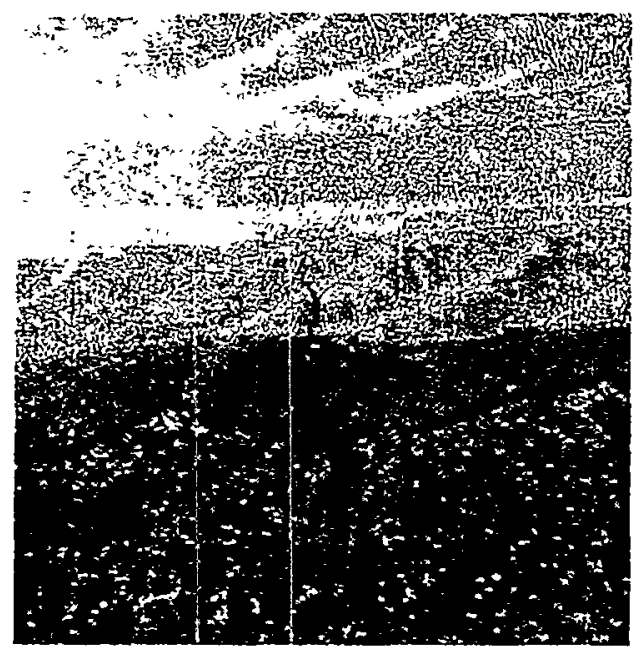

Figure 5. H-13 tool steel, deposited by LENS (top) and spray-forming (bottom). Note altered microstructure and crack at interface.

In addition, metallography has revealed the presence of small cracks at the interface between the spray-formed and LENS deposits and bands adjacent to the interface where the microstructures of both the spray-formed material and LENS deposit have evolved substantially. Further investigation into the interfacial cracking mechanism would be warranted.

Alloy studies conducted at Sandia and ORNL revealed that LENS processed H13 had excellent properties as deposited. The use of LENS as a process for the production of tooling makes good metallurgical sense. Further, there appears to be an opportunity to fine tune the composition of $\mathrm{H} 13$ tool steel to take advantage of the rapid solidification environment which is available within LENS. Although no special H13 powder compositions were produced, ORNL did provide some Nickel Aluminide powder of a proprietary composition. This alloy is a hard high strength material that is difficult to work using conventional processes. However with the LENS process, near net shape objects were produced and subsequent testing at ORNL revealed excellent properties.

\section{SUMMARY}

The System of Labs effort was plagued in both years by late funding allocations. Lack of support at the INEEL end for the second year also forced them to withdraw from the project prematurely. However, significant and useful results were obtained at both ORNL and SNL as a result of this collaboration. This program helped support the following presentations and publications:

\section{Laser Engineered Net Shaping}

Eric Schlienger, Sandia National Laboratories, Albuquerque NM Automotive Applications of Thermal Spray Technology 
Romulus MI June 3, 1998

\section{Near Net Shape Production of Metal Components using LENS}

Eric Schlienger'; Duane Dimos ${ }^{1}$; Michelle Griffith ${ }^{1}$; Joseph Michael ${ }^{1}$; Mike Oliver'; Tony

Romero'; John Smugeresky ${ }^{2}$

${ }^{1}$ Sandia National Laboratories, Albuquerque, NM USA

${ }^{2}$ Sandia National Laboratories, Livermore, CA

Third Pacific Rim International Conference on Advanced Materials and Processing

Honolulu, Hawaii - USA : Jul - 12 thru Jul - 16

\section{Thermal Behavior in the LENS Process}

M. Griffith, M.E. Schlienger, J.A. Brooks, L. Harwell, M. Essien, Nelson and W. Hofmeister:

Sandia National Labs

Ninth Solid Freeform Fabrication Symposium

Austin TX, August 10-12,.1998

\section{Sacrificial Materials for Complex Geometry Fabrication}

M.E. Schlienger, M. Oliver and J.A. Romero: Sandia National Labs

Ninth Solid Freeform Fabrication Symposium

Austin TX, August 10-12, 1998

\section{ACKNOWLEDGMENTS}

This work was supported by the US Department of Energy under contract DE-AC0494AL85000.

\section{REFERENCES}

1 D. M. Keicher, J. L. Jellison, L. P. Schanwald, J, A. Romero, and D. H. Abbott, "Towards a Reliable Laser Powder Deposition System Through Process Characterization", $27^{\text {th }}$ International SAMPE Technical Conference, Vol. 27, Diversity into the Next Century, Proc., of SAMPE '95, Albuquerque, NM, Oct. 12-14, 1995, p. 1029.

2 D. M. Keicher, J. A. Romero, C. L. Atwood, J. E. Smugeresky, M. L. Griffith, F. P. Jeantette, L. D. Harwell, and D. L. Greene, "Laser Engineered Net Shaping for Additive Component Processing", Proc. of Rapid Prototyping and Manufacturing '96, Dearborn, MI, Apr. (1996).

3 D. M. Keicher, J. A. Romero, F. P. Jeantette and L. P. Schanwald, "A Method and System for Producing Complex Net-Shape Objects", patent pending.

4 Clyde O. Brown, Edward M. Breinan, and Bernard H. Kear, U. S. Patent \#4,323,756, "Method for Fabricating Articles by Sequential Layer Deposition," (To United Technologies) April 6, 1982.

5 Eric Schlienger, Duane Dimos, Michelle Griffith, Joseph Michael, Mike Oliver, Tony Romero, John Smugeresky, "Near Net Shape Production of Metal Components using LENS", Proceedings of the $3^{\text {rd }}$ Pacific Rim International Conference on Manufacturing, 1999. 
UNLIMTTED RELEASE

INITIAL DISTRIBUTION

MS 0958 M. L. Griffith, 1484

MS 1411 M. S. Oliver, 1831

MS 1411 D. Dimos, 1831

MS 1434 J. J. Jellison, 1803

MS 0899 Technical Library, 4916 (2)

MS 9018 Central Technical Files, 8940-2 (1)

MS 0612 Review \& Approval Desk, 4912 For DOE/OSTI

MS 0188 LDRD Office, 4001 